Article

\title{
Application of the Integrated Design Process (IDP) Method to the Design of Riverside on the Example of Żmigród (Poland)
}

\author{
Anna Bocheńska-Skałecka *(1) and Ewa Walter(D) \\ Institute of Landscape Architecture, Wrocław University of Environmental and Life Sciences, Grunwaldzka 55, \\ 50-357 Wrocław, Poland; ewa.walter@upwr.edu.pl \\ * Correspondence: anna.bochenska-skalecka@upwr.edu.pl
}

Received: 31 May 2020; Accepted: 14 August 2020; Published: 18 August 2020

check for updates

\begin{abstract}
Today, natural resources of urban areas have been given the rank of a necessary tool for combating climate change. Many cities are trying to manage biologically active areas of great quality by applying a blue-green infrastructure (BGI) strategy. Designing areas such as riverside areas belonging to BGI is particularly challenging. On the one hand, they are environmentally valuable areas requiring protection. On the other hand, they form urban public spaces subject to requirements of urban continuity as well as social and cultural conditions. The authors of the article argue that the optimal way of shaping riverside areas in cities that responds to diverse conditions (environmental, economic, legal, social) can be achieved by applying an integrated system of cooperation between designers known as the integrated design process (IDP) in the design process. The study aimed to answer the question of whether the integrated design process (IDP) that combines both the expert and social approach at the first stage, in the pre-concept phase may be optimal when developing riverside areas as part of blue-green infrastructure (BGI). The method was originally applied to architectural design, therefore the authors analyzed to what extent its assumptions may be used in the waterfront design process. First, the authors' study compares design processes (traditional and integrated) for use in these processes of expert and social perspective. As a result, the integrated design process (IDP) has been considered as an optimal design process to create such areas. Then, the authors analyze the waterfront design process in Żmigród. The authors wanted to see to what extent the process corresponds to the assumptions of the IDP method. The authors point out the stages that implement assumptions of the IDP method partially or not at all and indicate the reasons for such a situation. The authors evaluated the role of various stakeholders. The analysis and critique of Żmigród case study presented here provide conclusions regarding the possibilities and limitations of the IDP method when implementing blue-green infrastructure projects in a small town.
\end{abstract}

Keywords: integrated design process; riverside landscape designing; blue-green infrastructure (BGI); community participation; Żmigród

\section{Introduction}

Lately, European cities have been increasingly pursuing climate change adaptation policies, not only to mitigate the negative effects of climate change, but also to provide future effective tools and mechanisms for sustainable cities which results from the European Union guidelines. Today, natural resources of urban areas have been given a rank of a necessary tool for combating climate change [1]. They have been called 'green infrastructure'. According to the strategy adopted by the European Commission: Green Infrastructure (GI)—Enhancing Europe's Natural Capital (2013), 'green infrastructure' is a strategically planned network of high nature value areas, designed and 
managed to deliver a wide range of ecosystem services and to conserve biodiversity in rural and urban settings [2]. The natural environment, within the concept of 'ecosystem services', provides services on which human existence depends. The purpose of the above is to ensure respect for the environment, which is an important partner for policymakers at various levels. The strategy has identified that 'green infrastructure incorporates green and blue areas. It can play an exceptionally important role in cities providing services that include flood protection, strengthening water retention and flood prevention, maintaining groundwater at a proper level, and restoring or averting the loss of biodiversity [2]. Over time, an increasing number of researchers tended to use the term 'blue-green infrastructure' (BGI), which strongly indicates areas of actions and indissolubility of certain systems. The term was first used for describing the planning efforts in Sao Paolo, Brazil, aimed at flood control [3]. Nowadays, blue-green infrastructure is often interpreted (an engineering approach) as a tool for sustainable water management in the city while supporting the functioning of grey infrastructure [3]. It should not be forgotten that BGI stems from GI. Therefore, it should aim at managing biologically active areas of great quality [1,4] (pp. 15-36). BGI enhances the natural value of areas, and thus its economic and social value $[1,4]$ (pp. 15-36). The creation or restoration of BGI means more than just environmental benefits for cities. It is often the restoration of cultural heritage and local identity e.g., involving the relationship between the city and the river [5,6] (pp. 169-206). The implementation of blue-green infrastructure is not always easy and is hampered by barriers such as low public awareness of BGI benefits, inadequate BGI management, or maintenance costs [1,7]. Dynamically managed large cities with a substantial budget carry out programs and strategies to implement BGI [3]. Smaller cities, often far from the mainstream, focus more on local problems such as economy, employment, or labor migration. Their budget is not sufficient to invest in BGI with the same intensity as large metropolises. Paradoxically, smaller cities very often have valuable, high-quality natural resources, but they are not in a position to use their potential for creating and managing blue-green infrastructure.

It is extremely difficult to maintain biologically active areas of great quality, which are also urban public areas since, on the one hand, they require protection, and on the other hand, they require adaptation to social purposes. Typical examples are parts of river valleys dividing urban tissue, which are valuable habitats of fauna and flora as well as recreational areas appealing for urban residents. Some reviewers take the view that economic development of waterfronts should not preclude their natural features and local authorities should to take into account integrated and balanced waterfront planning. Sustainable development of riversides can be achieved only when environmental, social, and economic aspects are well integrated [8,9] (pp. 552-586), [10]. Innovative waterfront design may be achieved, only owing to the cooperation of experts forming a multidisciplinary team along with representatives of society $[10,11]$. Improvement of design processes is essential for building and maintaining a sustainable environment in this context. Reconciling the coexistence of natural and artificial environment is one of the topics currently raised by designers [12] (pp. 95-111). The issue relates by far to the design and implementation of a project in urban waterfront areas [13].

This paper presents the authors' results of research on the most appropriate waterfront design method. The authors analyzed the waterfront design process for the integrated design process (IDP) method applied in architectural design. The key research question was: Can the IDP method be used in waterfront design in the context of creating blue-green infrastructure? The authors reviewed the literature focusing on two matters. The first one is the relationship between the city and the river reaching a contemporary approach to waterfront designing as an element of a blue-green network. The second matter is a review of design methods, where authors focus on the IDP method. The authors examined waterfront design processes in Żmigród concerning practices. The aim was to check to what extent the process is consistent with assumptions of the IDP method and diverges from the method. We evaluated the process (subsequent stages) and the role of individual stakeholders. Our conclusions show indications for implementing the IDP method in the waterfront design. 


\section{Literature Review}

\subsection{Riparian Zone Development in the Context of the Transformation of City-River Relation}

A lot of cities grew out of a small settlement located along a river, because its proximity delivered numerous benefits $[10,14]$. Riverside towns offered an easy access to transport and communication routes, thus determining their development [14-16]. Riparian areas served also important social functions as natural recreational facilities for inhabitants [6,15-18]. Public green space was situated directly on or in close proximity of embankments $[15,19]$. Over the years, rivers determined not only an urban structure and development, but had a significant importance in shaping urban identity as they influenced the landscape attractiveness $[15,19]$. The panorama of the Danube added to the list of UNESCO World Heritage [20] is an example of space where a river does not exist without a city and the other way round, for together they form a unique landscape. Skalski [21] even claimed that the ability of cities to use the proximity of the river (in the different aspects: Economic, natural, social, etc.) reflects its attitude to sustainable development and historical legacy. For centuries, the city-river relation has been subject to transformation and it has never been easy. As civilization grew and urban areas expanded, rivers, as a natural enclave, have been declining $[19,22]$. Increasing floods and environmental pollution caused separation of cities from rivers as they were canalized and sometimes filled in $[15,23]$. For many years, man contributed to transformations of river valleys and, consequently, this induced changes in hydrographic conditions, pollution, and deterioration of habitats in this area [15,19,22,24].

Nowadays, cities are seriously affected by extreme climatic events such as floods caused not only by climate change regime. In a broader context, they are a consequence of uncontrolled urbanization expansion (deforestation, soil sealing, canalizing, or river straightening) while water resources have been unreasonably managed for centuries (excessive water abstraction, water transfers, drainage of lands for development purposes, impoundment of water, construction of dams, a wasteful model of production and consumption). Water and climate change in cities induce lowering of the soil water table, the drying-up of natural water ecosystems (ponds, small ponds, wetlands), pollution caused by surface runoff and increased inundations and flooding, an overload of an urban sewer system, and construction disasters. Therefore, in many urban agglomerations, actions of local authorities are aimed at restoring the water balance of urban areas and mitigating the effects of disturbances [25,26]. Researchers worldwide are involved in developing strategies for sustainable water resource management on a large scale/the management of large-scale water resources as well as tools and technologies for use on a small scale [3]. Lerner and Holt [14] hold the view that the interactions between cities and their rivers are a complex mix of gains and challenges for a city. However, in recent years, rivers have become more valuable. According to the authors, people realized that natural systems must be protected and reinforced if we are to rely on services provided by these ecosystems [14]. With the benefit of hindsight, the symbiosis between cities and rivers may have a timeless relevance. River valleys are a valuable natural resource for cities serving an irreplaceable ecological function $[10,14,27]$ and being a foundation of the blue and green infrastructure. Again, riverside areas are of interest to administrators of cities as priority areas for local plans and strategies $[25,26,28]$. In contemporary waterfront-planning, priority is given to environmental benefits (flood prevention, protection of habitats, maintenance of good quality water) $[8,23,24]$ while making the space more attractive to a user [15,29]. Timur [6] (pp. 169-206) claims that the visual impact of water on landscapes is the main factor for attracting people to waterfronts. Water is the key element of planning as it provides people with physical and mental wellbeing $[12,18,30]$. Cengiz [9] (pp. 552-586) argues that people should be able to have an up-close experience with a river. Such physical and visual sensation helps to create diverse places in cities encouraging a feeling of belonging and appreciation of nature. Nonetheless, it works both ways. As argued by Wolski and Jankowski [22] in the context of city-river relations, the concept of space is closely linked to a local community that fully integrates the concept of a riverside area. The existing interdependence stems from the attributes and formation of community [22]. The educational process aimed at increasing 
the social awareness of the roles that rivers play is not without significance. Hence, rivers should be included in the active process of waterfront restoration $[15,16]$.

Social impact of waterfront development is also vital. The identities of many cities were formed based on a river that affected inhabitants and their connection with waterfront landscape [16,23]. Restoration of this connection through waterfront development responding to the needs of users may impact the restoration of urban identity. Cengiz [9] (pp. 552-586) claims that the shaping riverside landscape should cover the extensive participation of diverse community members that is extended beyond traditional groups of stakeholders. Holt et al. [24] points out that the stakeholders should switch over time and link the needs of regional and urban networks with local interests. They find that when implementing a project, process management must provide sufficient flexibility to deal with a complex and dynamic nature of the environment and be stable to maintain trust and legitimacy among parties involved.

A lot of authors stress that the revival of riparian areas is impossible without taking into account their cultural continuity $[5,6,22,23]$. Throughout the centuries, the ecological and cultural functions of rivers developed simultaneously at the same time forming a unique composition of urban morphology [5]. The natural and cultural landscape of revitalized waterfronts should interpenetrate each other. Wolski and Jankowski [22] add that in the age of sustainable development, a river should be the hallmark of a city, a showroom of urban life and its integration. The process of designing riparian areas should be based on searching for new factors of local development linked to tradition, history, and culture of a given location. At the same time, the direction of development orientated on nature and landscape ought to be strengthened as it will improve climatic and hydrological conditions, increase biodiversity, and create inhabitant-friendly recreation space [15].

\subsection{Design Process Approach Versus Shaping of Riverside Areas}

A supra-local look and outreach activities based on interdisciplinary cooperation at various stages of project implementation are required to restore natural functions in urban areas [24,28]. It should be stressed that riverside areas, especially within built-up areas, participate actively in recreation space $[13,15]$. Consequently, the creation of such space is a broad and multi-faceted issue. On the one hand, there are natural areas where expert knowledge about how to develop and manage them is required $[15,31]$. On the other hand, urban riverside areas as public spaces require a social approach allowing user primacy $[13,15]$.

An expert perspective, characteristic for designers, is linked to a selection of research methods defined by a design process. Basic methods include an analysis of formal and legal requirements and field studies that form a part of pre-project activities and talks with an investor or its representatives $[12,15,32,33]$. Public consultation is an additional element. A designer's creative process is an essential component of action [12,32,34]. From a social point of view, however, mainly for the community representing social sciences (sociologists, psychologists, cultural experts), typically all measures are undertaken in cooperation with representatives of various social groups, both formal and informal, in the social participation process $[15,33]$. Researchers studying riparian areas $[12,15,32,33]$ believe that the creation of such areas requires not only a comprehensive and systemic approach but should also take into account the dynamics of the fast-changing design process. Constant monitoring of the process, and thus identification of breakpoints, will ensure that design decisions are more efficient in terms of economics, ecology, culture, and society $[15,33]$.

The objective can be achieved if a design process model for developing riparian areas addresses an expert and social view from the outset-at the stage of studies and analyses (a pre-concept stage). This, in turn, directly relates to organizing an interdisciplinary project team already at an initial stage. A lot of researchers analyzing the design process and its effects $[12,32,33,35]$ say that the progressive and therefore sustainable design is impossible without a strong, integrated design team. Based on the authors' research and by comparison with others [33,35], in the authors' opinion, when creating riparian 
areas, the work of an interdisciplinary team should be initiated at the first stage of the design process. It will also make it possible to apply methods and tools typical of an expert and social approach.

\section{Study Area}

Żmigród is an urban-rural municipality. It covers an area of $292 \mathrm{sq} . \mathrm{km}$ and has a population of 14,688 inhabitants [36] of which $43 \%$ account for the inhabitants of Żmigród (the town). The original settlement grew beside the Barycz River, the channels and oxbows of which surrounded the old town. Żmigród obtained borough rights in 1253 and started developing rapidly while shifting away from the Barycz River covering its channels and oxbows. Today, the town is divided by the Sasiecznica River, which is the left tributary of the Barycz River and initially it was located outside the urbanized area (Figure 1). The part of river valley, situated in the center of Żmigród, is an important element of its structure. The Sasiecznica River together with its tributaries is a low-level watercourse and the alarm level is exceeded occasionally [37]. Water levels exceeded alarm thresholds in 2017 and 2019 last time (data from Regional Water Management Board, Lower Silesia, Poland). Only 40\% of the Sasiecznica Valley is natural, the remaining part-to the mouth to the Barycz River is strongly transformed, mainly because the river was regulated in 2003 as part of then-current method of flood prevention [37]. The nature of Sasiecznica River is homogeneous within the town. A large part of the valley with remainders of oxbows has retained its quasi-natural character with wide broads and vegetation typical for riverside habitats. Żmigród Municipality is marked by numerous historic, cultural, and natural features. Owing to the particular natural and cultural values of the region, hiking and cycling are developing strongly. They are key pillars of the economy of many municipalities including Żmigród.

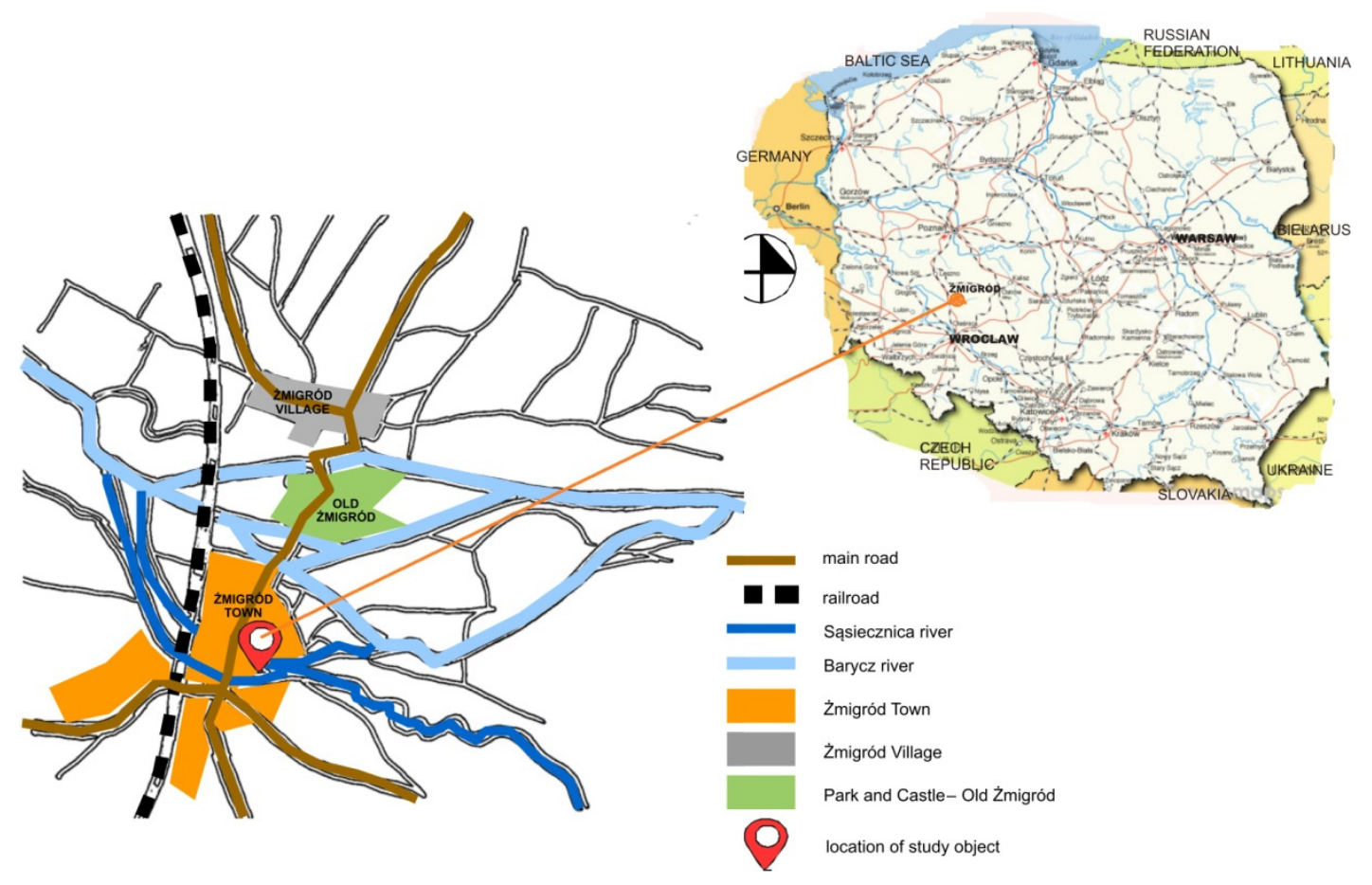

Figure 1. Żmigród, the town located along the Sasiecznica River.

Żmigród Municipality does not have a separate development strategy of blue-green infrastructure. Despite the enormous natural potential, there is no common planning and management system for these areas. This is partly due to the model of the administrative structure in Poland, which is too fragmented. Areas having different functions have different managers, even if, from a natural point of view, they form a single ecosystem. It very often happens that different organizational entities pursue similar objectives, e.g., strengthening of small water retention, achieved through separate plans or 
programs that do not form a systemic solution for the entire region. Żmigród Municipality has two formal documents that specify tools for sustainable water management: "Environmental Program for Żmigród Town and Municipality" and "The strategy of sustainable development for Żmigród Municipality for the years 2015-2020" [17].

The "Land Development of the Sasiecznica River in Żmigród" Project implemented over the period of 2015 to 2018 pursues objectives set out in the strategy of the municipality; it also addresses the long-term objectives of the "Environmental Program for Żmigród Town and Municipality" [38]. It is not linked to other actions regarding water resources of the municipality. It is not a part of a systemic approach. However, it is important to underline that one of the priorities identified by the investor has been to preserve as many existing environmental values as possible, thus, not to interfere significantly with the natural character of vegetation and precious waterside habitats. The areas by the Sasiecznica River were intended to become a key element of BGI for Żmigród Town and Municipality: Areas representing high natural values and leisure and educational function serving both the inhabitants of the municipality and tourists. The investment was also in line with the needs of the residents formulated in a study conducted by the municipality in 2015 [39]. The research showed that for the respondents the proximity of nature is the greatest asset of the inhabited village. The inhabitants of the commune indicated safety in public places, availability of places for recreation and leisure, as well as cleanliness of the natural environment.

With regard to the main objectives, the solutions required to maintain, conserve, and enhance biodiversity in a given area have been applied based on the existing environmental conditions. The most important added element includes water features that is basins with marsh vegetation (native species occurring in a given habitat) to collect water from high levels occurring periodically. Water features have been introduced because of environmental reasons (low retention, increase of biodiversity), aesthetic reasons (diversification of a monotonous landscape), and educational reasons (growth of environmental awareness, in particular increasing knowledge on small retention and protection of wetland habitats). Elements of infrastructure that allow safe use of the site recreation and leisure have been used as part of development. In order to highlight the cultural values of the area, and thus renew the identity of the place, a sculpture relating to the town's coat of arms (a tail of a dragon) was placed together with a mock-up of the town and a description of the most important historical architectural dominants in the town panorama. As it is true for the majority of projects of this type, the riverside design process included different groups of participators, among them, an investor, a designer, a contractor, governing bodies (institutions), and recipients. External experts (a geologist, a hydrologist, and a constructor) assisted in solving some design problems. Many solutions proposed by the investor were in response to inhabitants' needs expressed in the research report entitled: "Żmigród Municipality in the opinion of its residents. Report from the research 2015" [39].

\section{Research Approach}

An integrated system of cooperation between designers known as the Integrated Design Process-IDP is a model (system) of the design process that shapes the sustainable built-up area [35,40-43]. It is not the same as "inter-branch coordination", (the conventional design process, $\mathrm{CDP}$ ), (Figure 2a) commonly known and used in practice (Figure 2b).

The IDP seeks to establish a set of criteria for the design process to keep the following parties interested:
1. Investors,
2. Designers,
3. Users.

These criteria include:

1. Users' health,

2. Comfort 
3. Productivity,

4. Flexibility of a project regarding future requirements,

5. Operation and maintenance of systems,

6. The life cycle costs of a project,

7. Social links,

8. The context of environment,

9. Culture and habits.

Nils Larsson [43] defines the process as follows: "The Integrated Design Process (IDP) is a method of intervention in early stages of the design process that supports the development and design team to avoid sub-optimal design solutions". It is a methodical approach applied in architectural design in the 1990s when constructing high-performance buildings. Such buildings are characterized by reduced greenhouse gas emissions and energy as well as drinking water use [27,43-45]. Nowadays, they are known as green architecture or sustainable architecture, and their construction and functioning entail obtaining a quality certificate (identifying the positive impact on the environment) $[45,46]$. Thanks to the cooperation of all interested parties and external experts, the objectives shall be achieved. A mediator as a person responsible for the smooth conduct of the process during its entire duration also makes an important contribution $[45,46]$. Traditional stages of a project do not disappear in IDP, they are carried out differently (Figure 2a,b). This is due to the introduction of a simulation of proposed solutions at each stage of work. It is becoming easier and more common owing to advances in information and communication technology, including setting up of databases as well as programs that support designing. A sustainable project is often linked to the concept of sustainable community [42], which is a community that follows sustainable development principles: Healthily, economically using renewable energy. The link between areas for living and public transport (its accessibility) sharing a common green area near home or public space are also very important. The IDP is popular in Canada, the USA, and New Zealand, where projects financed by the government and local authorities are sometimes also carried out according to the LEED (Leadership in Energy and Environemntal Design-certification system) requirements [42,45]. It allows for an assessment of service of a project and verification of adopted solutions. A real teamwork carried out from the beginning of the design stage is one of the main factors affecting the effectiveness of the IDP. A line-up of a project team, which works on a project from the beginning, is crucial for the implementation of the objective of creating a sustainable space. In the authors' view, due to the interdisciplinarity of the specialty, the presence of a landscape architect in the team is necessary from the very beginning of the design process [47-49]. Despite the difficulties in defining the profession of a landscape architect and the discipline [47-49], the area of competence and activities of these professionals offers a multifaceted and systemic approach to a design problem.

According to the results, the authors claim that the most appropriate design process to be used when developing riverside areas should be the one that combines both the expert and social approach at the first stage, namely the pre-concept phase. As part of such process an interdisciplinary design team develops the stage of strategy and scenarios for the contemplated project, and the process does not end with the completion of the undertaking. The presented model of the design process-integrated design process-seems appropriate for structuring riverside areas considering the importance of the monitoring stage of project operation. This aspect seems to be crucial with a view to enabling further research on sustainable riverside development.

The research approach is a single case of the design process of riparian development in a small town (Żmigród), which has undergone an as-built assessment after its completion and in the first year of operation. The assessment was based on the initial design objectives, the course of the process, and involvement of individual groups of stakeholders in the subsequent stages as well as compliance with the integrated design process (IDP).

The research material consisted of:

- Notes from the public consultation carried out during stage IV of the design process, 
- Observations and notes from the design process,

- Complete design documentation,

- Formal and legal documents of the 'Land Development of the Sasiecznica River in Żmigród Project',

- A record of an interview with the investor after putting the project into service, stage $V$ of the design process,

- Notes from the public consultation carried out after putting the project into service, stage $\mathrm{V}$ of the design process,

- Field observation after putting into service of the project, stage $V$ of the design process,

- A record of an interview with the investor one year after putting the project into service, stage $\mathrm{V}$ of the design process,

- Field observation one year after putting into service of the project, stage $\mathrm{V}$ of the design process.

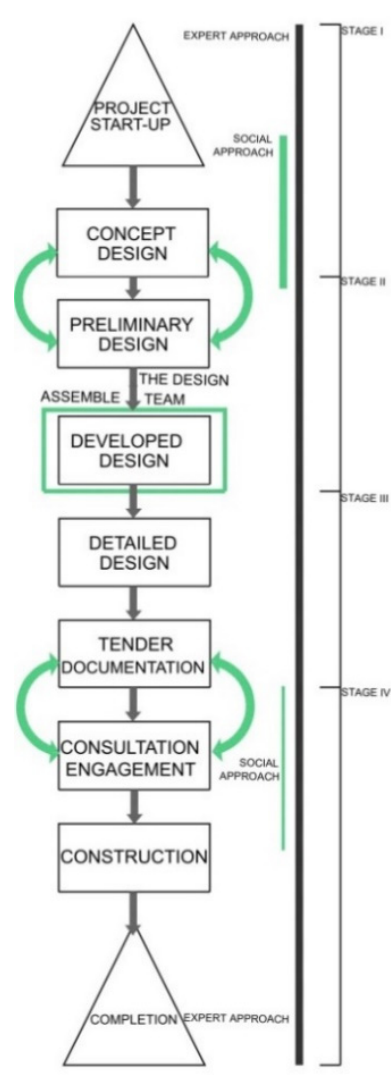

(a)

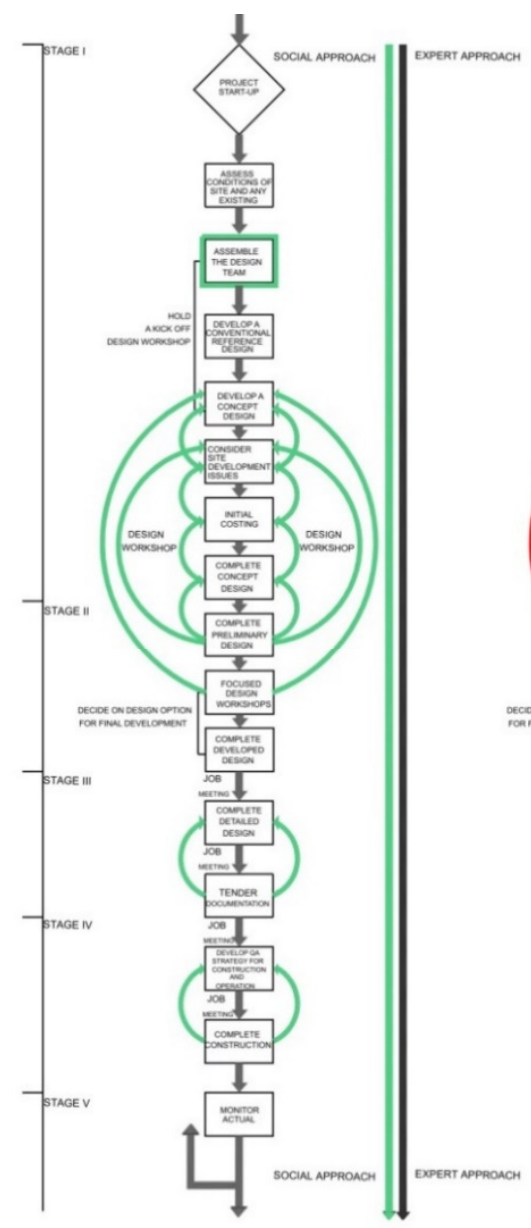

(b)

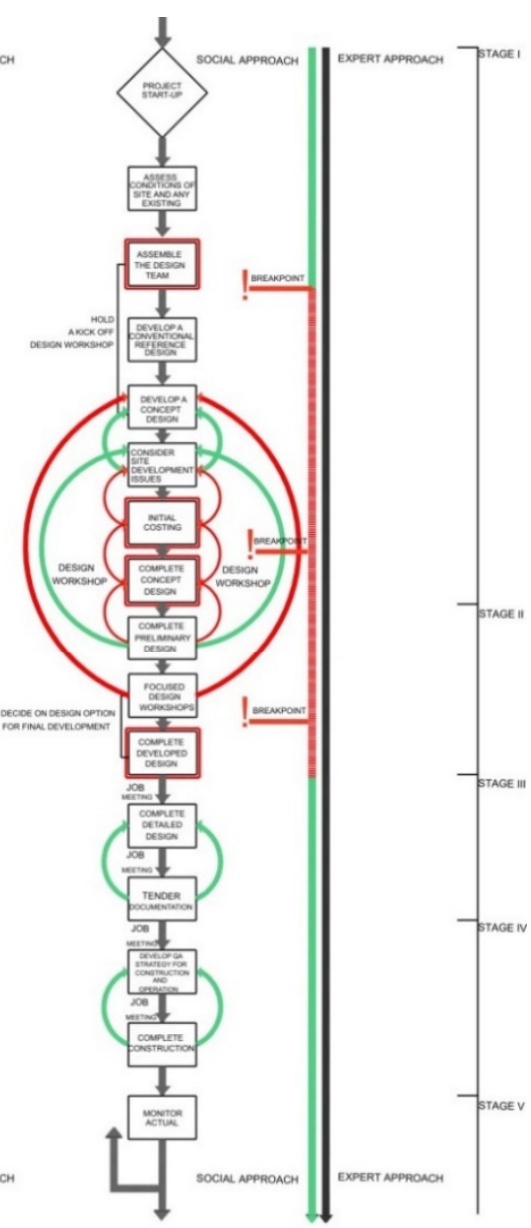

(c)

Figure 2. Comparison of conventional design process (CDP) design process, the integrated design process (IDP), and the Design Process in Żmigród: (a) The figure identifies the linearity of the conventional design process (CDP) from project start-up to construction and completion. The CDP is developed by categorizing it into components with minimal interaction between the design team members. Possible feedback loops (shown by the green arrows) only between part of stage 1 and 2 and part of stage 3. Assemble the design team-stage II (the authors' own research); (b) the figure identifies the interactive of the integrated design process (IDP) from project start-up to commissioning and post-occupancy evaluation and the possible feedback loops (shown by the green arrows) at stage 1 to 4. Assemble the design team-stage 1 (adapted from Larsson [43]); (c) the figure identifies stages of the Design Process in Żmigród in relation to the assumptions of the IDP method, detailing the breakpoints loops (shown by the red), (the authors' own research). 
In the first stage, an analysis of source materials has identified current trends in urban riparian development. It helped specify the priority actions taken in the development of sustainable environment. The next step was to translate the IDP method applied mainly in architectural design into the land development process with reference to the previously identified priority actions. Furthermore, the analysis of formal documents of Żmigród Municipality has defined formal tools owned by the municipality intended for planning and implementation of sustainable development projects, including blue-green infrastructure projects. At this stage, design activities have been identified and ranked according to formal and legal procedures. Individual stakeholders have been assigned a specific role in every activity. Next, breakpoints, that is moments leading to a change in the design process in relation to the design intent, have been identified [50]. The analysis of the design process in Żmigród with respect to the guidelines of the integrated design process (IDP) method has been a final part of the authors' research in order to answer the question whether the riverside design process in Żmigród met the key assumptions of the IDP method. At this stage, breakpoints that affected activities in the process as well as implementation of respective land development components have been examined. Breakpoints were analyzed identifying their status concerning the original design objectives (plus-constance-minus) and the possibility of verification at an initial stage to provide an answer to the question: 'Are they dependent or independent on a designer?' Each breakpoint has been linked with a factor and/or stakeholder that caused them. Regarding the objectives of the IDP method, stages of the design process in Żmigród proceeded in a similar way. Stage I is marked by more dynamic activities, including occurrence of feedback loops representative for IDP feedback. The diagram shows the design process (Figure 2c), including breakpoints. The three most important breakpoints that changed the design process as compared with initial assumptions have been identified. Two points occurred during the stage I and one point during the stage II. Breakpoints resulted from the following determinants:

1. Social—making the investor accustomed to conventional design process (CDP);

2. Economic-minimizing implementation cost;

3. Formal-unclear law.

The results of the analysis can be used as recommendations on the improvement of the IDP method with respect to the riverside design process (Integrated Riverside Landscape Design).

\section{Results and Recommendations}

The riverside design process in Żmigród has been implemented in compliance with the policy for areas of specific nature (riparian) proven by research $[6,8-10,29]$ and tested in model projects $[11,18,23,31]$. These are natural, social (or social and cultural), and economic determinants. The analysis of the process in Żmigród has shown that formal determinants, which may affect the process, are an essential aspect that should have already been considered at an initial stage of the process [50]. In the design process in Żmigród, formal activities stemming from formal determinants have taken a great deal of time in relation to other types of activities (Figure 3). On the other hand, too little consideration has been given to consultative activities. More intense activities are required at multiple stages with respect to the design method, IDP. In the design process in Żmigród as well as in the IDP method, the design workshop prevails among activities (Figure 3).

Table 1 describes in detail the design process in Żmigród compliant with the IDP method. The subsequent stages of the process and the most important activities affecting its dynamics have been shown with a particular focus on differences in relation to the preferred IDP model. 


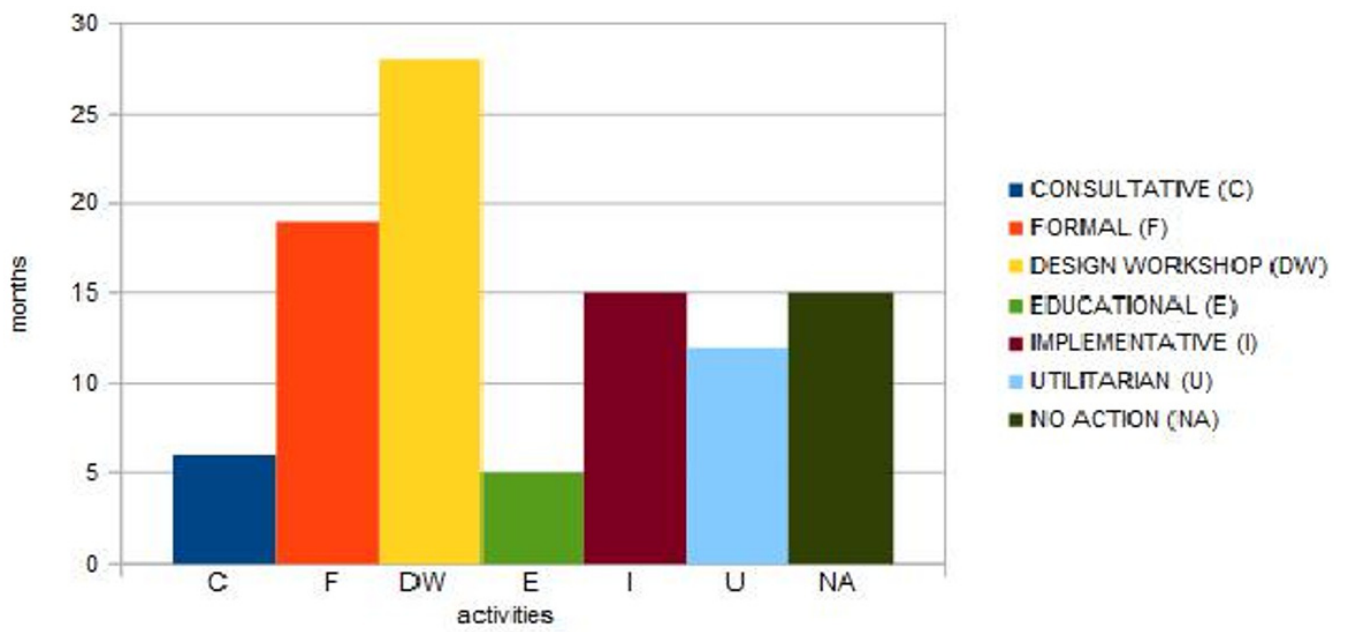

Figure 3. Duration (in months) of different types of activities in the waterfront design process in Żmigród (the authors' own research).

Table 1. The IDP versus the design process in Żmigród, comparison of the implementation of process stages.

\begin{tabular}{|c|c|c|c|}
\hline \multicolumn{2}{|r|}{ The Integrated Design Process (IDP) } & \multicolumn{2}{|r|}{ The Design Process in Żmigród } \\
\hline & Name of Steps & & Progress of Implementation \\
\hline \multirow{7}{*}{ 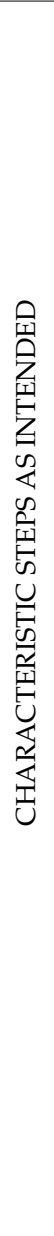 } & & & Stage I \\
\hline & $\begin{array}{l}\text { Review functional program; } \\
\text { establish preliminary targets }\end{array}$ & $\begin{array}{l}\text { Cause: } \\
\text { Effect: }\end{array}$ & $\begin{array}{l}\text { Specific conditions of the site: floodplains, of high natural value, } \\
\text { located in a direct vicinity of the town, neglected, not safe, } \\
\text { requiring an optimal land development. } \\
\text { Cooperation between the municipality and the research institute. } \\
\text { Transfer of knowledge and information. }\end{array}$ \\
\hline & $\begin{array}{l}\text { Assess conditions of site and } \\
\text { any existing }\end{array}$ & $\begin{array}{l}\text { Cause: } \\
\text { Effect: }\end{array}$ & $\begin{array}{l}\text { Specific conditions of the site: floodplains, of high natural values, } \\
\text { requiring protection and maintenance. } \\
\text { Consultations with experts (an irrigation agronomist (meliorant), } \\
\text { an environmental engineer). }\end{array}$ \\
\hline & $\begin{array}{l}\text { Assemble the design team, } \\
\text { identify missing specialties }\end{array}$ & $\begin{array}{c}\text { Breakpoint: } \\
\text { Cause: }\end{array}$ & $\begin{array}{c}\text { No design team, identify missing professionals and users. } \\
\text { Cost minimization during the initial stages of design, getting the } \\
\text { investor accustomed to the Conventional Design Process (CDP). } \\
\text { The team lacks all professionals: a hydrogeologist, a design } \\
\text { engineer, an estimator. Lack of jointly taken design decisions. } \\
\text { Lack of some analyses or expert reports due to the nature of } \\
\text { the areas. } \\
\text { No social participation—-no identification of design objectives. }\end{array}$ \\
\hline & $\begin{array}{l}\text { Develop a conventional } \\
\text { reference design } \\
\text { Develop a concept design } \\
\text { Consider site development issues }\end{array}$ & Cause: & $\begin{array}{l}\text { Organization of a student design competition, design workshops } \\
\text { conducted by academics and consulted by experts (an irrigation } \\
\text { agronomist (meliorant), an environmental engineer). } \\
\text { Additional practical benefits (except for commercial) - } \\
\text { educational benefits. }\end{array}$ \\
\hline & Initial costing & $\begin{array}{l}\text { Breakpoint: } \\
\text { Cause: } \\
\text { Effect: }\end{array}$ & $\begin{array}{l}\text { No initial costing; } \\
\text { Cost minimization during the initial stages of design, getting the } \\
\text { investor accustomed to the Conventional Design Process (CDP). } \\
\text { Lack of define performance targets. }\end{array}$ \\
\hline & Complete concept design & $\begin{array}{l}\text { Effect: } \\
\text { Conclusion: }\end{array}$ & $\begin{array}{c}\text { No complete concept design. } \\
\text { No final decision on the investor's source of funding. } \\
\text { The decision was taken during II stage. } \\
\text { It necessitated modifications of design solutions adopted during } \\
\text { I stage. } \\
\text { Change of design solutions during II stage and III stage have been } \\
\text { made without sufficient consultation and analyses. }\end{array}$ \\
\hline
\end{tabular}


Table 1. Cont.

\begin{tabular}{|c|c|c|c|}
\hline \multicolumn{2}{|c|}{ The Integrated Design Process (IDP) } & \multicolumn{2}{|r|}{ The Design Process in Żmigród } \\
\hline & Name of Steps & & Progress of Implementation \\
\hline \multirow{11}{*}{ 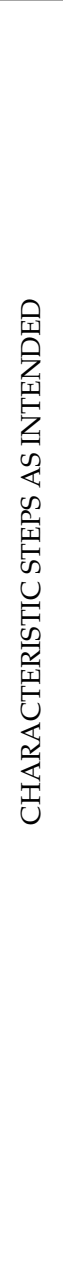 } & \multicolumn{3}{|r|}{ Stage II } \\
\hline & $\begin{array}{l}\text { Complete preliminary design } \\
\text { Focus on design workshop }\end{array}$ & & $\begin{array}{l}\text { Complete preliminary design } \\
\text { Focus on design workshop. }\end{array}$ \\
\hline & $\begin{array}{c}\text { Decide on design option for final } \\
\text { development }\end{array}$ & Breakpoint: & No decision on a design option for final development. \\
\hline & Complete developed design & Cause: & $\begin{array}{l}\text { Lack of some expert-based analyses. } \\
\text { Failure to obtain required permits and approvals under the } \\
\text { Completed developed design (1); Necessity to make amendments } \\
\text { and obtain approvals again. Additional costs and time extension. } \\
\text { Failure to submit documents related to applying for EU funding. } \\
\text { A low score obtained during the funding procedures. } \\
\text { Complete developed design (2) }\end{array}$ \\
\hline & \multicolumn{3}{|r|}{ Stage III } \\
\hline & $\begin{array}{l}\text { Complete detailed design. } \\
\text { Tender documentation. }\end{array}$ & & $\begin{array}{l}\text { Complete detailed design. } \\
\text { Tender documentation. }\end{array}$ \\
\hline & \multicolumn{3}{|r|}{ Stage IV } \\
\hline & $\begin{array}{l}\text { Develop QA strategy for } \\
\text { construction and operation. } \\
\text { Complete construction }\end{array}$ & \multicolumn{2}{|r|}{$\begin{array}{l}\text { Develop QA strategy for construction and operation } \\
\text { Complete construction }\end{array}$} \\
\hline & \multicolumn{3}{|r|}{ Stage V } \\
\hline & Monitor actual performance & & Monitor actual performance \\
\hline & Optimize performance & Cause: & $\begin{array}{l}\text { Cooperation between the investor-municipality and the research } \\
\text { institute in preparing the project strategy and arrangement. } \\
\text { Setting the secondary objective by the stakeholders: research and } \\
\text { educational objectives. } \\
\text { Joint analysis of observation carried out; planning and } \\
\text { introducing changes based on the observation (modifications of } \\
\text { land development elements). Field-based training for students. } \\
\text { Preparation of educational and scientific research where the area } \\
\text { would be "a landscape laboratory" and the stakeholders would } \\
\text { include: residents, students, pupils and academics } \\
\text { (stage: a description of the project drawn up in order to submit an } \\
\text { application for funding). }\end{array}$ \\
\hline
\end{tabular}

A study of the design process in Żmigród revealed that involvement of various stakeholders varied. One stakeholder exercised a dominant influence. It is a weak point of the process with regard to the IDP method. The most important difference between these designing methods (CDP and IDP) is providing a 'forum' under the IDP whose members work together on a design from the concept or even the stage of strategies or scenarios for developing a project to the verification of assumed parameters as partners. The aim is to develop optimal solutions by the design team. The design team should not be pressured by one of its members. What matters is the continuity of such process and that it is pursued even after a project acceptance procedure [40,42].

Table 2 indicates the impact of the stakeholders of the design process on decisions in relation to the components of land development during implementation. Implementation of 36 components of land development resulting from the design intent has been assessed. Nine of the studied components have been implemented without any changes, and two of them have not been implemented at all. The analysis has shown that as many as 27 components have been modified during design workshop-17 components have been changed having a positive effect and 10 components having a negative effect on the original concept. The Investor (18 modifications) had the greatest impact on changes, then there was the designer (7 modifications), and the contractor (7 modifications). Almost all the Investor and Designer's changes had positive effect, however the contractor's modifications had a mostly negative effect. Most of the changes were made at the design workshop stage (13 modifications). 
Table 2. The influence of stakeholders on the implementation of land development components (the authors' own research).

\begin{tabular}{|c|c|c|c|c|c|c|c|c|c|c|c|c|c|c|c|}
\hline \multirow{4}{*}{ No } & \multirow{4}{*}{$\begin{array}{c}\text { Elements } \\
\text { Developed }\end{array}$} & \multirow{4}{*}{ Investment Stage } & \multicolumn{6}{|c|}{ Execution } & \multirow{2}{*}{\multicolumn{6}{|c|}{ Participant Influence }} & \multirow{4}{*}{ Change (Stage) } \\
\hline & & & \multirow{3}{*}{$\begin{array}{l}1 \\
0\end{array}$} & \multicolumn{2}{|c|}{$\mathbf{A}$} & \multicolumn{3}{|c|}{ B } & & & & & & & \\
\hline & & & & 2 & 3 & 4 & 5 & 6 & \multirow{2}{*}{ I } & \multirow{2}{*}{$\mathbf{D}$} & \multirow{2}{*}{$\mathbf{S}$} & \multirow{2}{*}{$\mathrm{C}$} & \multirow{2}{*}{$\mathbf{U}$} & \multirow{2}{*}{ A } & \\
\hline & & & & + & - & - & + & - & & & & & & & \\
\hline 1 & CAR PARK & I-IV & & & $x$ & & & & $\mathrm{x}$ & & & & & $x$ & II \\
\hline 2 & BRIDGE & I-IV & & & $x$ & & & & & & & & & $x$ & II \\
\hline 3 & FOOTBRIDGES & I-IV & & & $\mathrm{x}$ & & & & & & & $\mathrm{x}$ & & & IV \\
\hline 4 & OBSERVATION DECK & I-IV & & & $\mathrm{x}$ & & & & $\mathrm{x}$ & & & $\mathrm{x}$ & & $\mathrm{x}$ & II/III \\
\hline 5 & OVERLOOK & I-IV & & $\mathrm{x}$ & & & & & & $\mathrm{x}$ & & & & & II \\
\hline 6 & PIT-STOP FOR BICYCLES & I-IV & & $\mathrm{x}$ & & & & & $\mathrm{x}$ & & & & & & II \\
\hline 7 & $\mathrm{BEACH}$ & I-IV & $\mathrm{x}$ & & & & & & & & & & & & 0 \\
\hline 8 & SQUARE FOR DOGS—1 & I-IV & & $\mathrm{x}$ & & & & & $\mathrm{x}$ & & & & $\mathrm{x}$ & & II \\
\hline 9 & SQ. FOR DOGS-2 & I-IV & & & $\mathrm{x}$ & & & & $\mathrm{x}$ & & & & $\mathrm{x}$ & & II \\
\hline 10 & SQ. FOR FOODTRUCKS & I-IV & $\mathrm{x}$ & & & & & & & & & & & & 0 \\
\hline 11 & FOOTPATHS & I-IV & & $\mathrm{x}$ & & & & & $\mathrm{x}$ & & & & & & IV \\
\hline 12 & RIPRAP & I-IV & & & $\mathrm{x}$ & & & & & & & $\mathrm{x}$ & & & IV \\
\hline 13 & PASS UNDER FLYOVER & I-IV & & $\mathrm{x}$ & & & & & $\mathrm{x}$ & & & $\mathrm{x}$ & & & IV \\
\hline 14 & OUTDOOR STAIRS & II-IV & & & & & $x$ & & & $\mathrm{x}$ & & & & & II \\
\hline 15 & FLOATS FOR FISHERMANS & I-II & & & & $x$ & & & & $x$ & & & & & II \\
\hline 16 & CHANNEL RENOVATION & III-IV & & $x$ & & & & & $\mathrm{x}$ & & & & & & IV \\
\hline 17 & CULVET RENOVATION & III-IV & & $x$ & & & & & $x$ & & & $\mathrm{x}$ & & & IV \\
\hline 18 & DRY STREAM & I-IV & & & $x$ & & & & & & & $x$ & & & IV \\
\hline 19 & CATWALK BY DITCH & I-II & & & & $x$ & & & $\mathrm{x}$ & & & & & & II \\
\hline 20 & FLOATS ON BEACH & I-IV & $\mathrm{x}$ & & & & & & & & & & & & 0 \\
\hline 21 & GABION SEATS & I-IV & $\mathrm{x}$ & & & & & & & & & & & & 0 \\
\hline
\end{tabular}


Table 2. Cont.

\begin{tabular}{|c|c|c|c|c|c|c|c|c|c|c|c|c|c|c|c|}
\hline \multirow{4}{*}{ No } & \multirow{4}{*}{$\begin{array}{c}\text { Elements } \\
\text { Developed }\end{array}$} & \multirow{4}{*}{ Investment Stage } & \multicolumn{6}{|c|}{ Execution } & \multirow{2}{*}{\multicolumn{6}{|c|}{ Participant Influence }} & \multirow{4}{*}{ Change (Stage) } \\
\hline & & & \multicolumn{4}{|c|}{ A } & \multicolumn{2}{|c|}{ B } & & & & & & & \\
\hline & & & 1 & 2 & 3 & 4 & 5 & 6 & \multirow{2}{*}{$\mathbf{I}$} & \multirow{2}{*}{ D } & \multirow{2}{*}{$\mathbf{S}$} & \multirow{2}{*}{$\mathrm{C}$} & \multirow{2}{*}{$\mathbf{U}$} & \multirow{2}{*}{ A } & \\
\hline & & & 0 & + & - & - & + & - & & & & & & & \\
\hline 22 & BENCHES & I-IV & & $x$ & & & & & & & & $\mathrm{x}$ & & & IV \\
\hline 23 & BICYCLE RACKS & I-IV & $x$ & & & & & & & & & & & & 0 \\
\hline 24 & BINS & I-IV & $x$ & & & & & & & & & & & & 0 \\
\hline 25 & EDUCATION BOARDS & I-IV & $x$ & & & & & & & & & & & & 0 \\
\hline 26 & DRAGON SCULPTURE & II-IV & & & & & $x$ & & $x$ & $x$ & & & & & II \\
\hline 27 & PICTURE WINDOW & II-IV & & & & & $x$ & & $x$ & $x$ & & & & & II \\
\hline 28 & TOYTOWN & II-IV & & & & & $x$ & & $\mathrm{x}$ & $x$ & & & & & II \\
\hline 29 & LIMB “ADDER” & III-IV & & & & & $x$ & & & $x$ & & & & & IV \\
\hline 30 & SCULPTURE DRAGON NATURALIST & IV & & & & & $\mathrm{x}$ & & $\mathrm{x}$ & & & & & & IV \\
\hline 31 & SCULPTURE DRAGON RIDER & V & & & & & $\mathrm{x}$ & & $\mathrm{x}$ & & & & & & V \\
\hline 32 & AGRICURTULAR DEVICE -EXIBITION & V & & & & & & $\mathrm{x}$ & $\mathrm{x}$ & & & & & & V \\
\hline 33 & AQUATIC GARDENS & I-IV & $\mathrm{x}$ & & & & & & & & & & & & 0 \\
\hline 34 & NEW GREENERY & I-IV & $\mathrm{x}$ & & & & & & & & & & & & 0 \\
\hline 35 & LIGHTING & V & & & & & $\mathrm{x}$ & & $\mathrm{x}$ & & & & & & $\mathrm{V}$ \\
\hline 36 & VIDEO SURVEILLANCE & V & & & & & $\mathrm{x}$ & & $\mathrm{x}$ & & & & & & $\mathrm{V}$ \\
\hline & AMOUNT: & & 9 & 8 & 7 & 2 & 9 & 1 & 18 & 7 & 0 & 7 & 2 & 3 & \\
\hline
\end{tabular}




\section{Recommendations:}

- To allocate more time and funds to the activities of the first stage of the design process.

- To form an interdisciplinary team of stakeholders at I stage of the design process, when developing a project strategy.

- When developing the strategy and plans, potential problems and limitations should be diagnosed thus to avoid any breakpoints within the planned process.

- A few scenarios of development of the design process should be formulated and cover the risk of not implementing some components.

- Create a few variants of the design concept and develop a final design concept within the interdisciplinary team.

- The consultative activities should be carried during all stages of the design process. This will enable to apply the social and expert approach simultaneously.

- A continuous project monitoring system should be developed in order to spot and eliminate problems during the initial stage.

\section{Conclusions}

The riverside design process in Żmigród may be called sustainable and partly consistent with the IDP method. On the one hand, the research revealed deficiencies and/or mistakes in the design process, while on the other hand it highlighted differences that may help adapt the IDP method better to riverside landscape design. The design process in Żmigród considered environmental, social, and economic factors. The research has shown that formal determinant is an important determinant of a proper riverside design process as it affects the process at different stages. In the design process in Żmigród, it included vague Polish law (the Construction Law, the Water Law Act) on floodplain development, which led to the adoption of assumptions proved to be insufficient to obtain approvals required under the current law. It is concluded that flexible conduct of the process is possible only at the stages independent of formal determinant.

An important finding is the fact that stakeholders affecting the design process at all stages in accordance with the IDP method should form a coherent team and be subject to a specified management system. An interdisciplinary project team should be formed at the first stage of the process when drawing up a strategy before a concept. That condition has not been met in the case of the design process in Żmigród and it has been a major weakness of the process. It also has a bearing on the process at subsequent stages, including the implementation of some land development components caused by shortage of experts in the team. Research results confirmed that consultative activities are a necessary condition for a sustainable design process. They should be carried out at the beginning of the process (during the stage of strategy) and then continued at subsequent stages. The delay of consultative activities during the design process in Żmigród (carried out at stage four of the design process) has resulted in the protests from local residents due to disinformation damaging their confidence in the local authority. A completed concept design is an essential part of the first stage. The analysis of the design process in Żmigród confirmed that the lack of final design concept resulted in subsequent shortcomings and amendments in a completed developed design (building permit design) and a completed detailed design prolonging the process (Figure 4).

Another finding of the research is that the strategy on area development and a range of scenarios and options regarding various determinants should be developed prior to the design process. The design process in Żmigród revealed that it is crucial, especially in case of the project budget. As during the first stage no final decision concerning the project funding was taken, some design solutions had to be modified during the design process.

To recap, the analysis of the design process in Żmigród has revealed that due to the specific nature of riverside they require a complex design approach. The IDP method may prove to be effective in riparian planning in order to create a sustainable environment meeting the needs of nature and 
humans. The example of Żmigród shows that adaptation of this method may be difficult due to formal determinants that are beyond the stakeholders' control.

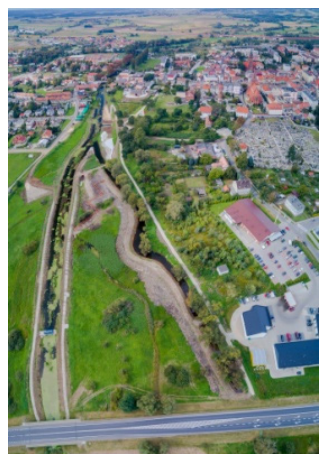

(a)

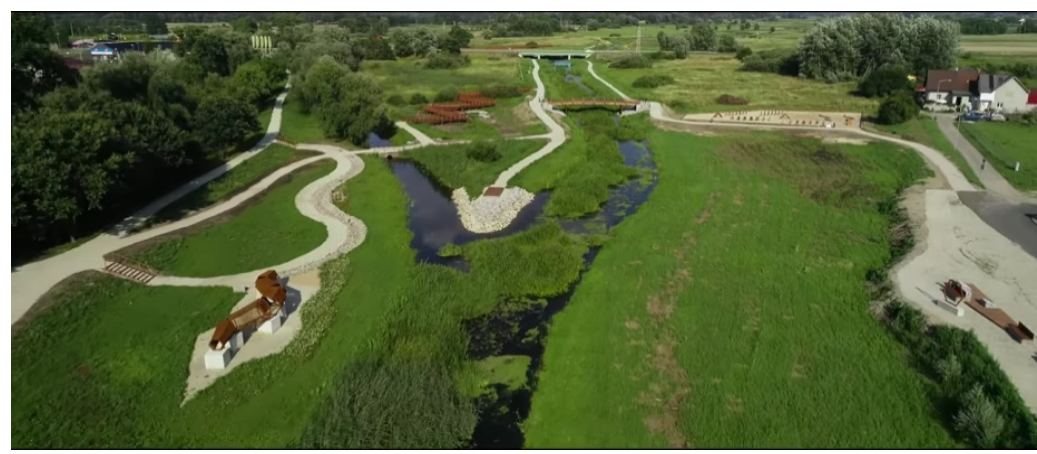

(b)

Figure 4. Aerial view of the investment area (a) 2018, in progress; (b) 2019, after completion of construction works.

The analysis and critique of Żmigród case study present conclusions regarding the possibilities and limitations of using the IDP method when implementing blue-green infrastructure projects in a small town. Sustainable development of urban waterfront requires a holistic approach. The coordination of the strategic objectives of management of urban areas, biologically active areas, and water at different levels (local, regional, and supra-regional) has a decisive impact on the effectiveness of implementing rules of sustainable development. It should also be pointed out that creating a communication (understanding) framework (forum) for all stakeholders during the design process contributes to developing social responsibility for shaping environmental. This will also make it possible to raise public awareness on the need for systemic and integrated measures where natural, cultural, social, and economic conditions are taken into account equally from the beginning.

Author Contributions: Conceptualization, A.B.-S. and E.W.; methodology, A.B.-S. and E.W.; formal analysis, A.B.-S. and E.W.; investigation, A.B.-S. and E.W.; resources, A.B.-S. and E.W.; data curation, E.W.; writing-original draft preparation, A.B.-S. and E.W.; writing-review and editing, A.B.-S. and E.W.; visualization, A.B.-S. and E.W. All authors have read and agreed to the published version of the manuscript.

Funding: This research received no external funding.

Acknowledgments: The Authors would like to thank to the Żmigród Council for its long-term cooperation and most of all for its support of the research work. Owing to mutual desire for continuous improvement, further design studies and research work contributing to science and to municipality development are planned.

Conflicts of Interest: The authors declare no conflict of interest.

\section{References}

1. Lamond, J.; Everett, G. Sustainable Blue-Green Infrastructure: A social practice approach to understanding community preferences and stewardship. Landsc. Urban Plan. 2019, 191. [CrossRef]

2. European Parliament resolution of 12 December 2013 on Green Infrastructure-Enhancing Europe's Natural Capital (2013/2663(RSP)). Available online: https://eur-lex.europa.eu/legal-content/EN/TXT/?uri=CELEX\% 3A52013IP0600 (accessed on 12 January 2020).

3. Ahmed, S.; Meenar, M.; Alam, A. Designing a Blue-Green Infrastructure (BGI) Network: Toward Water-Sensitive Urban Growth Planning in Dhaka, Bangladesh. Land 2019, 8, 138. [CrossRef]

4. Ghofrani, Z.; Sposito, V.; Faggian, R. A Comprehensive Review of Blue-Green Infrastructure Concepts. Int. J. Environ. Sustain. 2017, 6, 15-36. [CrossRef]

5. Chmielewski, T.J.; Kułak, A.A.; Michalik-Śnieżek, M. How to Evaluate and Forecast Changes in Landscape Image: The Case of a Small River Valley in Poland. Landsc. Res. 2015, 40, 466-475. [CrossRef]

6. Timur, U.P. Urban Waterfront Regenerations. In Advances in Landscape Architecture; Ozyavus, M., Ed.; IntechOpen: Rijeka, Croatia, 2013; Volume 7, pp. 169-206, ISBN 978-953-51-1167-2. [CrossRef] 
7. O'Donnelly, E.C.; Lamond, J.E.; Thorne, C.R. Recognizing barriers to implementation of Blue-Green Infrastructure: A Newcastle case study. Urban Water J. Vol. 2017, 14, 964-971. [CrossRef]

8. Apriliani, A.; Dewi, O.C. A study of cisadane riverside on riverbank development towards sustainability. IOP Conf. Ser. Earth Environ. Sci. 2020, 402. [CrossRef]

9. Cengiz, B. Urban River Landscapes. In Advances in Landscape Architecture; Ozyavus, M., Ed.; IntechOpen: Rijeka, Croatia, 2013; Volume 21, pp. 552-586, ISBN 978-953-51-1167-2. [CrossRef]

10. Iakovoglou, V.; Zaimes, N.G.; Gounaridis, D. Riparian areas in urban settings: Two case studies from Greece. Int. J. Innov. Sustain. Dev. 2013, 7, 271-288. [CrossRef]

11. Fernandes, D.T. An Integrated Approach of Landscape Design in Rehabilitation of Urban River Corridor: River Tinto. Proc. Fàbos Conf. Landsc. Greenway Plan. 2013, 4, 679-686.

12. Prokopska, A. Projektowanie Architektoniczne: Procesy Wstępne, 1st ed.; Oficyna Wydawnicza Politechniki Rzeszowskiej: Rzeszów, Poland, 2012; pp. 95-111.

13. Jagiełło-Kowalczyk, M.; Piwowar, K. Urban regeneration of riverside area in urban spaces. Środowisko Mieszk. Hous. Environ. 2018, 24, 13-22. [CrossRef]

14. Lerner, D.N.; Holt, A. How should we manage urban river corridors? Procedia Environ. Sci. 2012, 13, 721-729. [CrossRef]

15. Lis, A.; Burdziński, J.; Gubański, J.; Walter, E.; Bocheńska-Skałecka, A. Aktywizacja Przestrzeni Publicznych w Mieście-Ocena Potencjału Miejsc: Część, I. (Developing Public Urban Places in the City-the Evaluation of the Potential of Places: Part 1-Places along the River); Wydawnictwo Uniwersytetu Przyrodniczego we Wrocławiu: Wrocław, Poland, 2014. (In Polish)

16. Zhao, J.; Luo, P.; Wang, R.; Cai, Y. Correlations between aesthetic preferences of river and landscape character. J. Environ. Eng. Landsc. Manag. 2013, 21,123-132. [CrossRef]

17. Strategia Zrównoważonego Rozwoju Gminy Żmigród na Lata 2015-2020. Available online: http://www.zm igrod.com.pl/asp/pl_start.asp?typ=14\&sub=312\&menu=449\&strona=1 (accessed on 10 January 2020).

18. Virtudes, A.; Debicka, A.; Janik, L.; Barwinska, M.; Choinacka, N. City project by river fronts on behalf of university international research. In Proceedings of the 11th Annual International Conference of Education, Research and Innovation (ICERI 2018), Seville, Spain, 12-14 November 2018; pp. 4508-4517. [CrossRef]

19. Pancewicz, A. Ewolucja terenów nadrzecznych w miastach poprzemysłowych aglomeracji górnośląskiej-Poszukiwanie drogi ku realizacji idei miast zrównoważonych. Evolution of riverside areas in post-industrial cities in Upper Silesia agglomeration-Finding the way to sustainable cities. Studia Miej. 2015, 19, 59-73.

20. UNESCO. Available online: http://whc.unesco.org (accessed on 3 March 2020).

21. Skalski, J. Komfort dalekiego patrzenia a krajobraz dolin rzecznych w miastach położonych na nizinach. Comfort of long-distance perceiving and a landscape of river valley in towns situated on the plains. Teka Kom. Arch. Urb. Stud. Krajob. PL PAN 2005, 1, 44-52.

22. Wolski, A.; Jankowski, G. Riverside space and local communities. Selected theoretical aspects. Ecocycles 2019, 5, 33-38. [CrossRef]

23. Pancewicz, A. Rzeka w przestrzeni miejskiej. Próba określenia wzajemnych relacji. Rzeki Kult. Cywiliz. Hist. 2002, 11, 255-275. (In Polish)

24. Holt, A.R.; Moug, P.; Lerner, D.N. The network governance of urban river corridors. Ecol. Soc. 2012, 17, 25. [CrossRef]

25. Rotterdam. Climate Change Adaptation Strategy. 2013, City of Rotterdam. Available online: http://www.ur banisten.nl/wp/wp-content/uploads/UB_RAS_EN_lr.pdf (accessed on 25 January 2020).

26. The city of Copenhagen. Cloudburst Management Plan 2012. Available online: https://climate-adapt.eea.euro pa.eu/metadata/case-studies/the-economics-of-managing-heavy-rains-and-stormwater-in-copenhagen-201 3-the-cloudburst-management-plan (accessed on 3 January 2020).

27. Kowalski, P.; Scherzer, C. Riverside areas in cities as part of the Green Infrastructure system in the context of revitalization projects of the Garden Festival (Gartenschau) exhibitions in Germany. Środowisko Mieszk. Hous. Environ. 2018, 24, 120-129. [CrossRef]

28. RESTORE; European Centre for River Restoration (ECRR). Rivers by Design: Rethinking Development and River Restoration-A Guide for Planners, Developers, Architects and Landscape Architects on Maximizing the Benefits of River Restoration; Environmental Agency, Horizon House: Bristol, UK, 2010. 
29. Lis, A.; Walter, E.; Bocheńska-Skałecka, A.; Burdziński, J.; Gubański, J. Wrocław waterfront-Model features of riverside areas dedicated to students. Res. Pap. Wroctaw Univ. Econ. 2017, 490, 170-178. [CrossRef]

30. Stanisławska, M.; Marlinga, J.; Nowak, P.; Kaniewski, R. Program Ochrony Środowiska dla Miasta i Gminy Żmigród. Załącznik do Uchwały Rady Miejskiej Żmigród, Gmina Żmigród, 2004. Available online: https://zmigrod.ibip.wroc.pl/public/get_file_contents.php?id=172782 (accessed on 1 March 2020).

31. Lange, K.; Nissen, S. (Eds.) Urban river-Vital spaces. In Guide for Urban River Revitalization, 1st ed.; REURIS Project Team: Leipzig, Germany, 2012; ISBN 978-3-00-035317-8.

32. Groat, L.; Wang, D. Architectural Research Methods, 2nd ed.; Wiley: Hoboken, NJ, USA; Toronto, ON, Canada, 2012; pp. 425-449.

33. Horn, P. Zrównoważony Rozwój w Procesie Kształtowania Wspótczesnego Osiedla_Idee, Przykłady (Sustainable Development in the Process of Shaping a Contemporary Housing Estate. Ideas, Examples), 1st ed.; Oficyna Wydawnicza Politechniki Wrocławskiej: Wrocław, Poland, 2019; pp. 12-75. (In Polish)

34. Skalski, J.A. Analiza percepcyjna krajobrazu, jako działalność twórcza, inicjująca proces projektowania. The perceptive analysis of landscape as a creative action initiating the design process. In Treatises and Monographs; Publications of Warsaw Agricultural University: Warsaw, Poland, 2007.

35. Koch, C.; Buhl, H. "Integrated Design Process" a Concept for Green Energy Engineering. Engineering 2013, 5, 292-298. [CrossRef]

36. Statistics Poland-Główny Urząd Statystyczny, Bank Danych Lokalnych, Warsaw 2018. Available online: https://bdl.stat.gov.pl/BDL/start (accessed on 3 January 2020). (In Polish)

37. Hobot, A. (Ed.) Warunki Korzystania ze Zlewni Baryczy; Umowa nr ZZ-02/EP-224/2012 z dnia 19.07.2012 r.; "Pectore-Eco" Sp. z o.o.: Gliwice, Poland; MPWiK Sp. z o.o.: Kraków, Poland; Na zlecenie RZGW Wrocław: Wrocław, Poland, 2012. (In Polish)

38. Environmental Program for Żmigród Town and Municipality_Program Ochrony Środowiska dla Miasta I Gminy Żmigród. 2004. Available online: https://zmigrod.ibip.wroc.pl/public/?id=93096 (accessed on 13 January 2020).

39. Żmigród Municipality in the Opinion of Its Residents. Report from the Research 2015. Available online: http://www.zmigrod.com.pl/asp/pliki/pobierz/raport_zmigrod.pdf (accessed on 25 January 2020).

40. Bobbins, K.; Culwick, C. Green growth transitions through a green infrastructure approach at the local government level: Case study for the Guateng city-region. J. Public Adm. 2015, 50, 32-49, ISSN: 0036-0767. Available online: https://hdl.handle.net/10520/EJC175618 (accessed on 25 January 2020).

41. Gagnon, B.; Leduc, R.; Savard, L. From a conventional to a sustainable engineering design process: Different shades of sustainability. J. Eng. Des. 2012, 23, 49-74. [CrossRef]

42. Kujawski, W. Zintegrowany Proces Projektowy, czyli jak możemy projektować lepiej. Zawód Archit. Z A 2011, 1, 64-70.

43. Zimmerman, A. Integrated Design Process Guide. 2006, Canada Mortgage and Housing Corporation. Available online: http://www.infrastructure.alberta.ca/content/doctype486/production/leed_pd_appendix_7 a.pdf (accessed on 3 March 2020).

44. Klemm, W.; Lanzholzer, S.; Van den Brink, A. Developing green infrastructure design guidelines for urban climate adaptation. J. Landsc. Archit. 2017, 12, 60-71. [CrossRef]

45. Storey, S. Interim Report IR-10-014. Decision-Making for UBC High Performance Buildings: Multi-Criteria Analysis for Integrated Life Cycle Models. 2010. Available online: http://pure.iiasa.ac.at/id/eprint/9468/1/IR -10-014.pdf (accessed on 30 June 2020).

46. Zmigrod. Available online: http://www.zmigrod.com.pl/asp/pl_start.asp?ref=1\&typ=13\&sub=312\&menu= $2 \&$ strona $=1 \&$ schemat $=0$ (accessed on 3 March 2020).

47. Baird, T.C.; Szczygieł, B. Sociology of Professions: The Evolution of Landscape Architecture in the United States. Landsc. Rev. 2007, 12, 3-25.

48. Bocheńska-Skałecka, A.; Bocheński, S.; Kapusta, M. Współpraca architekta i architekta krajobrazu, jako jeden z proekologicznych trendów we współczesnym projektowaniu. (Capabilities partnership between architect and landscape architect as one the ecological trends in contemporary design. In Koncepcje $i$ Rozwiazania Proekologiczne w Architekturze Krajobrazu; Boczar, T., Wiszniowska, M., Eds.; Wydawnictwo Uczelniane: Szczecin, Poland; Państwowej Wyższej Szkoły Zawodowej im. Angelusa Silesiusa w Wałbrzychu: Wałbrzych, Poland, 2015; pp. 10-23, ISBN 978-83-63839-32-1. (In Polish) 
49. Available online: http://www.asla.org (accessed on 1 July 2020).

50. Walter, E.; Bocheńska-Skałecka, A. Importance of green infrastructure in a small town-A case study of design process of riverside areas in Żmigród. In Proceedings of the International Conference on Green Infrastructure "Current Status, Problems and Possibilities of Implementation Green Infrastructure in Modern Cities with Particular Emphasis on Green Roofs and Living Walls", Wroclaw, Poland, 19-21 September 2019.

(C) 2020 by the authors. Licensee MDPI, Basel, Switzerland. This article is an open access article distributed under the terms and conditions of the Creative Commons Attribution (CC BY) license (http://creativecommons.org/licenses/by/4.0/). 